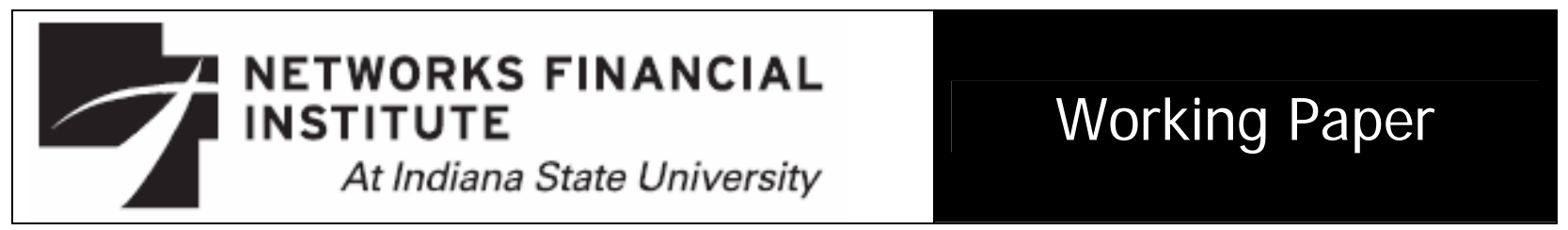

2005-WP-01

J une 2005

\title{
Deficits and the Economy: All Deficits Are Not Created Equal John A. Tatom
}

Abstract: Recent academic and popular discussions of budget deficits rely upon a simplistic and, in large part, false conception of their effects. The recent literature ignores the fact that deficit effects depend on their source and on private sector responses to them. It also matters whether budget changes arise passively through the workings of the business cycle and whether deficit-inducing policy actions are permanent or transitory. More often than not, deficits are associated with lower interest rates. One reason is that large movements in budget deficits are principally due to the business cycle. Recessions lower investment and interest rates and also lower capital inflows.

The widely popular idea that current account deficits arise from budget deficits is also not correct. Current account movements are related to international capital flows that respond more to incentives for domestic investment than to budgetary developments. Not surprisingly, the key expectations of the simple theory now circulating, especially about interest rates, the current account deficit and the dollar, are precisely opposite to what modern theory and evidence indicate. Investment and asset allocation decisions that rely on the popular misrepresentations of why and how deficits matter do material damage to investor interest.

About the Author: John A. Tatom is the Director of Research at Networks Financial Institute, part of Indiana State University, and Associate Professor of Finance at Indiana State University. He has published widely on international and domestic monetary and fiscal policy issues, especially inflation, capital formation, productivity and growth; the macroeconomics of supply, especially oil and energy price shocks; the relationship of exchange rate movements to international competitiveness, capital flows, trade, and international economic policy; and on financial innovations and their effects on monetary policy and the economy, among other areas.

Keywords: deficit, twin deficits, interest rates, fiscal policy

The views expressed are those of the individual author and do not necessarily reflect official positions of Networks Financial Institute. Please address questions regarding content to John A. Tatom at john.tatom@isunetworks.org. Any errors or omissions are the responsibility of the author.

NFI working papers and other publications are available on NFI's website (www. networksfinancialinstitute.org). Click "Research" and then "Publications/Papers." 


\section{Deficits and the Economy: All Deficits Are Not Created Equal}

\section{John A. Tatom}

How do deficits affect economic performance? The question has assumed new relevance in recent years, as many policymakers have voiced fears that ballooning federal deficits may harm the US economy. In turn, many have begun advocating against tax cuts on the grounds that they may increase deficits even further, leading to additional harm. But is this fear of federal budget deficits justified?

In Washington, the conventional wisdom espoused by many members of Congress—backed up by various academic studies ${ }^{1}$ - is that our current federal deficits threaten to harm the economy. According to this view, an increase in the budget deficit will lower national savings, causing interest rates to rise which, in turn, crowds-out private sector spending, especially investment. As a result of a decline in capital formation, productivity growth slows so that the standard of living of future generations is impaired. Finally, many argue, higher interest rates also will encourage foreign investors to purchase US bonds and other assets, pushing up the value of the dollar and increasing the current account deficit. ${ }^{2}$

There are two problems with this analysis. First, the premise that higher deficits raise interest rates is not supported by empirical evidence for the U.S., and second, even in most basic textbook models, the source of the deficit matters for assessing its economic impact. This paper takes the brief statement above of the conventional analysis, at least as captured

\footnotetext{
${ }^{1}$ See Gale and Orszag (2003), Rubin, Orszag and Sinai (2004) and Muehleisen and Towe (2004), for example. Textbooks are virtually unanimous in this view, at least in their presentation of the mainstream model linking government activity and interest rates. The restricted view of the economy and behavior leading to these results are illustrative, at best, yet serious researchers sometime overlook this. One example that has been pilloried in the popular press is Mankiw (2002) and Ball and Mankiw (1995).

${ }^{2}$ Some critics of deficits would go on to point out that the stimulative short-run economic effects of budget deficits would raise cyclical output and thereby boost inflation temporarily, reinforcing many of these adverse economic effects on the economy. To the extent that interest rate or exchange rate effects are absent, it is likely that these effects are also absent, however, because the interest rate effect and consequent exchange rate effect result from cyclical output effects that would also raise prices.
} 
by critics of budget deficits, as a point of departure. It argues that the analysis of budget deficits and their effects is much richer than this simplification and that this view obscures or ignores what has been known for decades about the theory of fiscal policy. Many of these theoretical considerations are also explained in elementary textbooks. More modern qualifications in the academic literature further reinforce the importance of the source of budget deficits in determining the effects of fiscal policy. ${ }^{3}$

\section{Budget Deficits and Interest Rates}

Do deficits raise interest rates? Historical evidence suggests not only that they do not, but in some cases the evidence points to a negative relationship between budget deficits and interest rates. There is considerable controversy over this relationship, however, and the result is sensitive to a number of statistical issues. Indeed, the observation of a negative relation is probably a meaningful statistical artifact, as explained below. In the jargon of economists or statisticians, empirical evidence on the link between interest rates and deficits is often referred to as "mixed" or "not robust." These characterizations are misleading. Usually it is simple to explain that a positive relation between deficits and interest rates sometimes occurs in a statistical test purely as the result of a statistical problem. If an adjustment is made for the factors giving rise to the result, the positive result disappears, i.e. the relationship is not statistically significant. In other words, one can disregard the positive relationship infrequently observed between interest rates and deficits. Some of the issues that make the results sensitive to the method of investigation are the measure of interest rates studied (real or nominal, long-term or short-term), the measure of government borrowing studied (various debt or deficit measures), expectations or actual measures of either interest rates or government borrowing, or whether other factors are included that are presumed to affect interest rates. ${ }^{4}$

\footnotetext{
${ }^{3}$ Brunner (1986) provides a summary of the academic literature that includes most of the qualifications of the simple textbook model that are discussed here. These considerations are even more generally accepted today and yet are widely overlooked in some recent literature and policy discussions.

${ }^{4}$ Reverse causality is conceptually an issue in looking at the influence of budget deficits on economic performance and prices such as real interest rates and exchange rates. For example, an increase in the real interest rate would raise the budget deficit by raising the interest cost of outstanding debt biasing up a positive relation between deficits and interest rates. It is the absence of such a positive relation that challenges conventional analyses and that is the focus here, but the issue warrants attention in efforts to explain budget balances. The deficit and its changes are taken as exogenous here, following the usual analysis of how budget deficits affect the economy or why they matter. However, another example of this problem is highlighted here:
} 
For example, in a provocative new paper, Engen and Hubbard (2004) argue that a onepercentage point rise in federal debt as a percent of GDP, about $\$ 110$ billion, will raise the real 10-year Treasury bond rate by 3 basis points. ${ }^{5}$ This effect, according to them, is statistically significant and precisely the amount to be expected from a long-run growth model. What they do not say, however, is that this effect is not economically significant. That is, it is so small as to be readily ignored for any practical purpose. A $\$ 400$ billion deficit, near the record level set in early 2004, would boost the interest rate by only 12 basis points. Other factors apparently dominate the actually observed movements in the real interest rates, as the real rate has fallen over 400 basis points since 2000 while the federal budget moved from a large surplus to deficit.

The largest swing in the federal debt held by the public (excluding the Federal Reserve) was from 21 percent of GDP in mid-1981 to 44.8 percent in the first quarter of 1994, except for a plateau at about 35.5 percent from early 1987 to mid-1989. This swing, according to the Hubbard and Engen result, would raise the real 10-year Treasury rate by 71 basis points. Yet over the period the real interest rate did not rise. At the end of the period it was 3.85 percent, down 2.26 percentage points from about 6.11 at the beginning of 1982. If there was a 71 basis point rise in there, it was swamped by other factors depressing the real rate. Similarly, the debt fell subsequently to 27.5 percent in early 2002. This decline would lower real rates by about 51 basis points and the real rate actually fell by 37 basis points over the period.

Taken at face value, the evidence indicates that budget deficits have little meaningful effect on interest rates. In some respects, this is a happy medium between analysts who conclude

the business cycle. Budget balances are pro-cyclical and it is well known that this imparts a negative relationship between interest rates and deficits. To test the effects of fiscal actions on the economy and interest rates in particular, structural or high-employment budget changes or components are typically used or else the influence of the business cycle is explicitly taken into account.

${ }^{5}$ Engen and Hubbard's conclusion rests on a conventional Keynesian model where the effects of deficits are assumed to have the maximum effects on interest rates. When the behavioral relationships emphasized here apply, then there is no effect of deficits on interest rates in their approach. They do not discuss these possibilities. Instead they focus on the conventional case, yet they still find only a 3-basis point effect per percentage point of debt relative to GDP as a maximum and long-run effect. 
that deficits do raise interest rates and those who conclude that they do not. Another reason that some analysts do not think that deficits affect interest rates is that government borrowing is small relative to the size of the capital markets. Federal debt has been less than 25 percent of the value of the private sector capital stock since the late 1950s and is less than 25 percent of domestic nonfinancial debt since the early 1960 s. $^{6}$

It is no accident that a Treasury bill rate of near 1 percent accompanied a relatively large budget deficit during 2004. When the economy is in recession or in the early stages of an economic expansion, private sector credit demand is weak. Businesses do not expand inventory or investment spending at a pace that matches increasing saving, which allows interest rates to fall to unusually low levels.

Cyclical deficits arise from a weak economy where unemployment is relatively high and incomes are relatively low, and therefore tax receipts are low and unemployment compensation is high. During such times, private sector spending and credit demands weaken more than government borrowing increases, so that interest rates are depressed. When the cyclical expansion begins to boost credit demand, interest rates rise, but the expansion of income leads tax receipts to rise and the budget deficit to shrink.

This is the usual cyclical pattern that has been borne out in the past four years. Even if we account for cyclical variations in the deficits, however, the result is that there is no correlation between interest rates and the budget deficit.

\footnotetext{
${ }^{6}$ There are numerous studies that indicate that deficits or debt have no effect or a negative effect on interest rates. As Gale and Orszag (2003) note, Barth, Iden, Russek and Wohar (1991) found a preponderance of evidence in tens of studies showing that deficits have no effect on interest rates. This is the same conclusion as in CBO (1989) which reviewed 25 studies. A majority of studies since then find that deficits raise interest rates, according to Gale and Orszag. The issue is resolvable by majority rule, however. As Gale and Orszag explain, more recent studies that find a positive effect of deficits on interest rates use expected future deficits instead of actual deficits. Unfortunately, as discussed below, expected deficits are unrelated to actual future deficits, but are influenced by the business cycle. It is likely that it is the latter relation that drives the empirical results, not the former. Laubach (2003) provides one of the first studies to use forward-looking estimates of the real interest rate with expected future deficit measures and finds a significant positive effect of deficits on interest rates. However, he includes a measure of the equity premium that is also cyclical and that biases upward his estimate of the effect of the deficit on interest rates.
} 
Figure 1 shows the real three-month Treasury bill rate, based on inflation measured over the past year using the personal consumption expenditure deflator, along with the budget surplus measured as a percent of GDP for the period 1960 through the first quarter of 2004. The correlation coefficient between the quarterly movements in the two measures is 0.17 , indicating that increases in the budget surplus are associated with increases in interest rates, or that deficits and interest rate movements are significantly negatively correlated.

\section{Figure 1}

\section{Federal budget deficits are not positively related to interest rates}

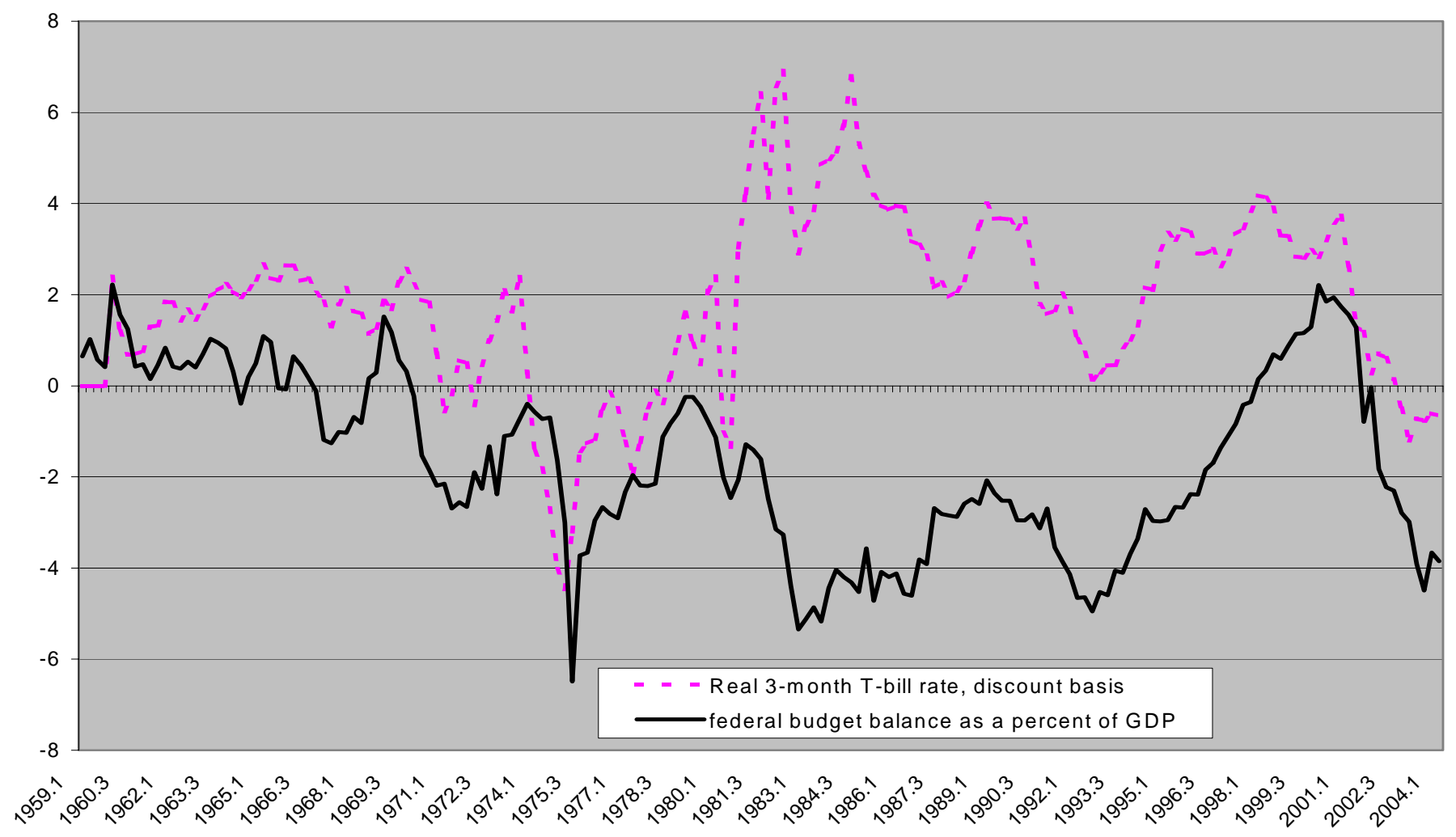

Some analysts ${ }^{7}$ have suggested that a better test of whether deficits lead to higher interest rates is to look at the impact of expected future deficits. The argument is that if market

\footnotetext{
${ }^{7}$ See Rubin, Orszag and Sinai (2004), and Feldstein (1986). Rubin and Orszag (2003) point to 12 of 17 studies that use an expected future deficit measure and find a positive significant effect, while 25 of 41 studies that use the current deficit do not find a significant positive effect. The 16 studies that use a current deficit measure and find a significant positive effect also include other measures that are correlated with the business cycle. This is an example of multicollinearity. Since the deficit and other measures are both affected by business cycle changes, the relationship between the deficit and the other included variables will dictate the sign and significance of the deficit measure as much or more than whether the deficit actually affects interest rates. There are ways to fix this problem, but they are not usually addressed in the studies of the deficit-interest rate
} 
expectations are rational, the current budget deficit is already anticipated. Thus, any market reaction to a higher current deficit would have come earlier when it was a surprise, if indeed it was a surprise. When expected future deficits are used, studies find that deficits appear to have a significant positive effect on interest rates.

Figure 2

\section{Expected future budget deficits also are inversely correlated with real interest rates}

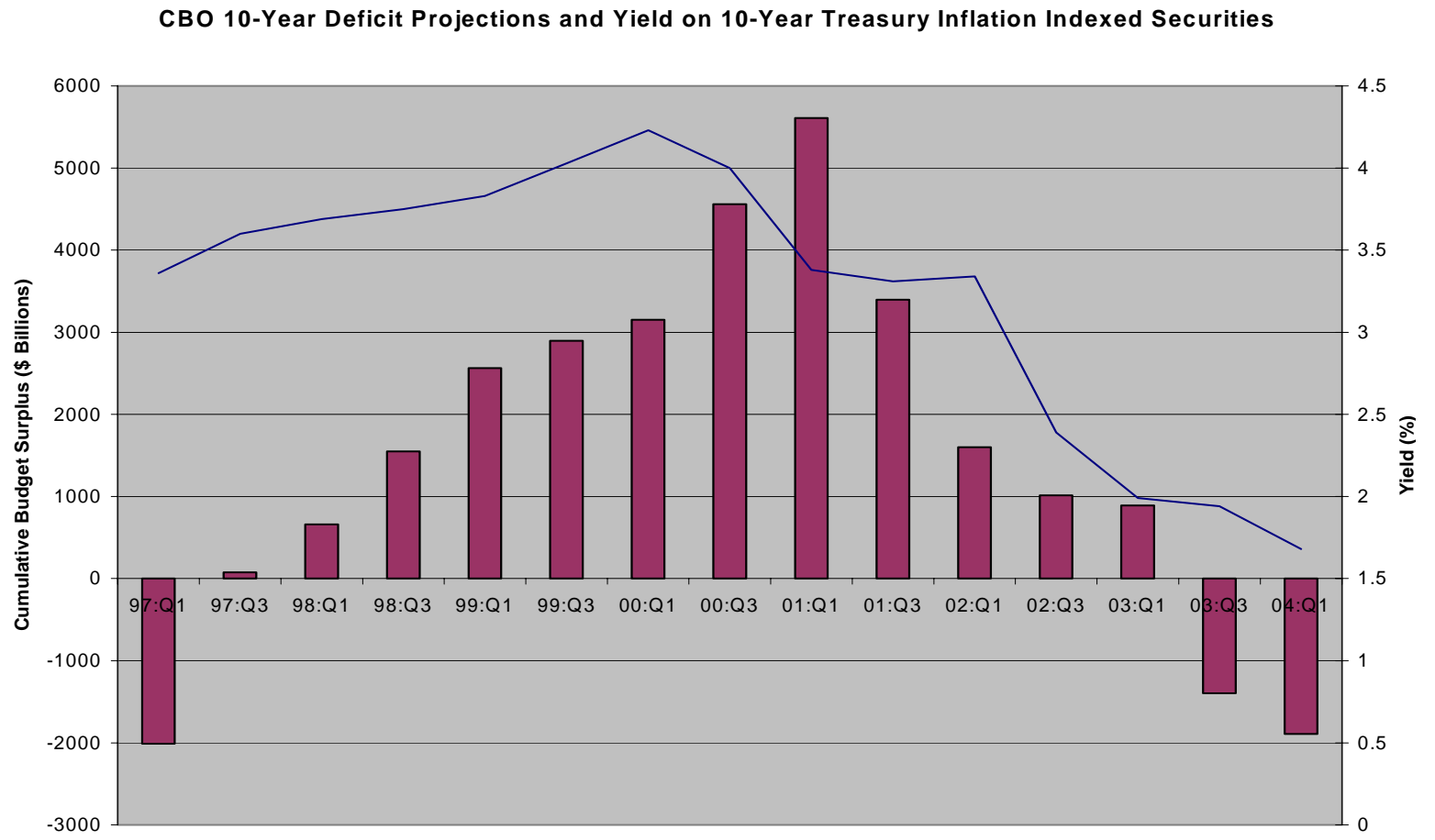

The problem with this approach, however, is that these expected future deficits-as measured using CBO forecasts-bear no relation to budget deficits that actually occur. Kliesen and Thornton (2001) studied the five-year cumulative deficit forecasts conducted by the CBO each year between 1977 to the present, and found no correlation between the actual cumulative deficits and the CBO’s forecasted deficits. ${ }^{8}$ Hence, any relationship of interest

connection. In Engen and Hubbard (2004), when current interest rates and debt or deficit measures are used, there is no significant effect of the fiscal measure on the current real interest rate. They emphasize a small (3basis point) effect, which is only significant when a projected debt or deficit measure is used with current or forward-looking real interest rates.

${ }^{8}$ Beginning in 1994, the CBO shifted emphasis to newly developed 10-year estimates, but five-year cumulative deficit estimates are available since 1977. 
rates to the CBO's expected deficit is either spurious or reflects a fundamental breakdown in rational expectations.

A more recent study by Kliesen (2002) analyzed the relationship between the real interest rate, measured by the rate on 10-year Treasury inflation-protected securities (TIPS), and the CBO's expected cumulative deficit over the next 10 years since the inception of TIPS in 1997. An updated version of his chart is shown in Figure 2. It indicates a strong negative correlation between expected future deficits and the real interest rate.

\section{Do Budget Deficits Cause Current Account Deficits?}

A related claim is that higher interest rates supposedly caused by budget deficits will also cause an inflow of foreign capital, causing the current account deficit to deteriorate. This "twin deficits" hypothesis was popular in the 1980s. However, there is not a significant positive correlation between the budget deficit as a percent of GDP and the current account deficit as a percent of GDP. ${ }^{9}$

Figure 3 illustrates the mixed relationship between budget deficits and current account deficits. For example, from 1992 to 2000 the budget deficit fell from 4.7 percent of GDP to a surplus of 2.4 percent of GDP, but the current account deficit deteriorated from 0.8 percent to 4.2 percent of GDP.

\footnotetext{
${ }^{9}$ Kormendi and Protopapadakis (2004) provide new statistical evidence against the twin deficits hypothesis.
} 


\section{Figure 3}

\section{Budget deficits and current account deficits usually do not rise and fall together}

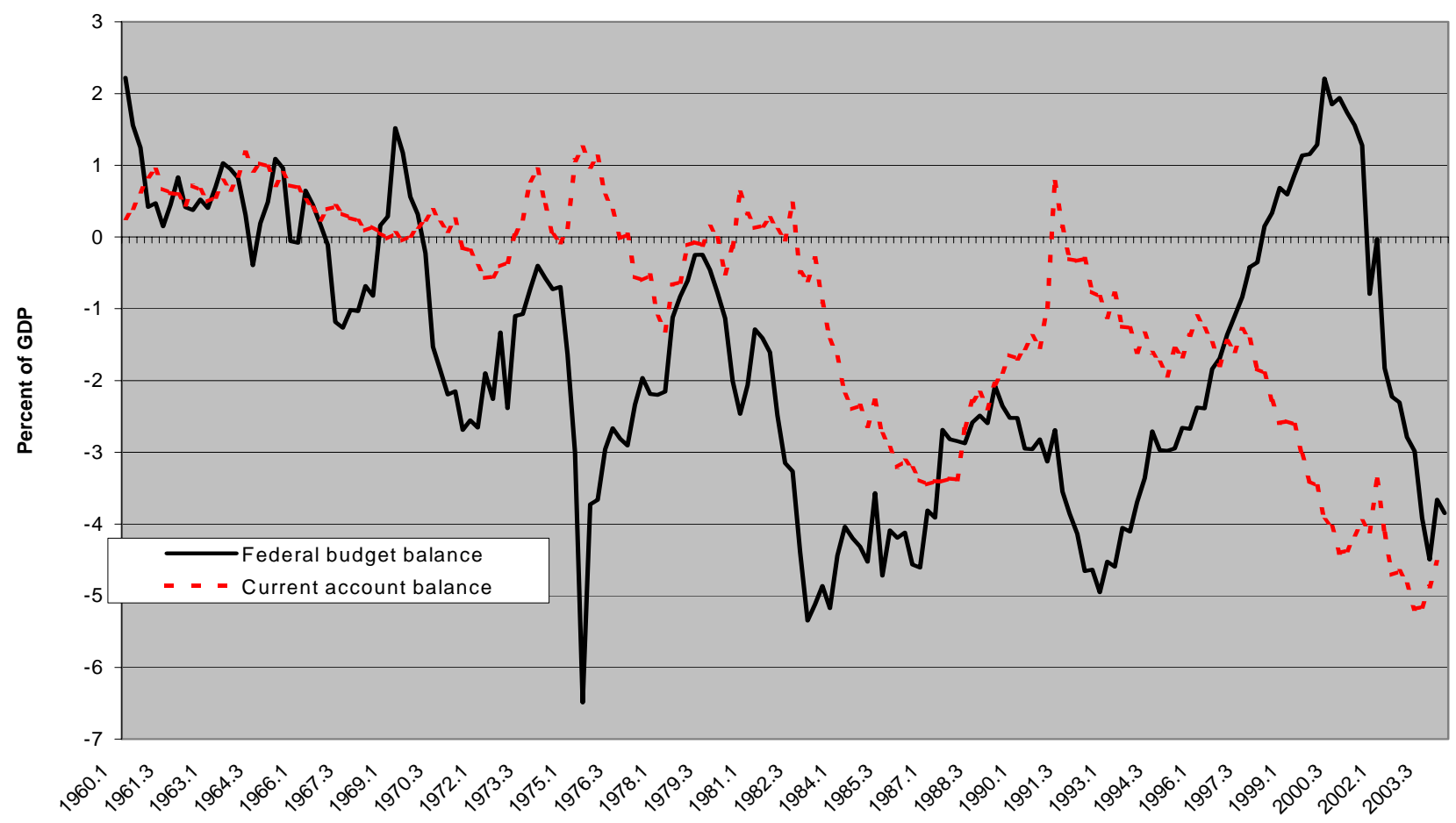

The correlation coefficient between the budget deficit and the current account deficit from 1960 through the end of 2003 is essentially zero (0.04). Like higher interest rates, larger current account deficits and growing net indebtedness to foreigners do not arise because of budget deficits.

\section{Not All Deficits Are Created Equal}

Recent analyses of the effects of deficits mistakenly treat all or most deficits the same in terms of their effects on the economy. This is confused, as not all deficit increases have the same effect on national saving, interest rates, investment, output, employment and growth, even in the standard Keynesian approach underlying these studies. ${ }^{10}$

\footnotetext{
${ }^{10}$ Some contributions to fiscal policy analysis that are ignored by recent deficit critics stress offsetting private sector responses to government fiscal policy actions. These include Barro (1981), Kormendi (1983) and Aschauer (1985). Powerful global evidence that budget deficits are often fully offset by changes in private sector saving is provided for OECD countries in de Serres and Pelgrin (2002). Bailey (Chapter 9, 1971), was the first to develop private sector reactions to government consumption and investment expenditures and to
} 
For example, in conventional or Keynesian models, cyclical budget deficits cushion the size of the decline in output and employment during recessions, and provide a more stable longterm outlook for the economy. Such cyclical declines in tax receipts and increases in transfer payments are generally regarded as having favorable effects on economic performance. Such deficits do not crowd-out investment and slow growth. These considerations are important and now often overlooked by deficit critics analyzing the economic impact of deficits. ${ }^{11}$

While tax cuts were not the major source of the recent deficit increase, to the extent that tax cuts did contribute to the emergence of the deficit, they did not crowd out investment. ${ }^{12}$ As with cyclical deficits, budget deficits caused by tax reductions also do not reduce national savings and crowd out investment in the same way as spending increases. For example, business tax cuts that boost budget deficits have a direct and exactly equal offsetting effect on business profits and private saving. Thus, they do not reduce national saving. They also have important effects on business investment if they are associated with a reduction in the cost of capital or increase in the after-tax rate of return on new investment. Most business tax cuts do precisely that, so they boost investment, and raise productivity and the standard of living.

Business tax incentives are not all the same either, at least in terms of their effects on incentives or on spending. The evaluation of the efficiency of tax incentives does not simply depend on their effects on spending. For example, a temporary cut in marginal tax rates or tax breaks tied to business spending could provide similar incentives to invest, but with a tax rate cut many firms would benefit even if they do not invest or do not invest more

deficits that would include complete direct crowding-out so that fiscal deficits would have no effect on output or interest rates in an otherwise standard Keynesian model.

${ }^{11}$ Under the more classical permanent income hypothesis, where spending depends on a longer-run notion of income than current receipts, cyclical tax and transfer changes that cushion the cycle's effects on output and employment do so by transferring part of the private sector's saving reduction in a recession into a "government saving" reduction.

\footnotetext{
${ }^{12}$ See Tax Foundation (2004). The increase in outlays accounted for 70 percent of the $\$ 648$ billion swing from
} surplus to deficit from 2001 to 2004, while weak receipts accounted for about 30 percent. 
than they would have in the absence of the tax rate cut. When a tax cut is tied to spending, more spending is likely to occur. Even then, some businesses benefit even if they do not alter their capital spending plans. Real "fine-tuners" sometimes try to limit benefits to only those who really step up spending compared with what they otherwise would spend, but this invariably complicates the tax code and leads to efforts to game the system using scarce resources. Fortunately these efforts to narrowly define the relevant margins for benefit qualification typically fail. Even when more spending is promoted by tax incentives, efficiency can suffer. Investment that would not be profitable otherwise takes place and comes largely at the expense of future investment. The timing of investment is affected even if the long-term capital stock is not.

This analysis is illustrated by the 2002 tax incentives for business investment spending. The availability of "bonus depreciation” for investment in equipment over the next three years did not lower national saving or private investment, but instead boosted both. Moreover, the 2002 business tax incentives were temporary, another key issue in assessing the effects of a budget deficit. Since these incentives disappeared in 2005, business had an incentive to alter the timing of future investment expenditures, making investment outlays in 2002-04 that would have occurred after 2004. This reallocation had positive short-term effects on output and employment and little effect on long-term growth. In 2010, for example, the nation's capital stock and productivity is not likely to be any different than it would have been without the business tax incentives. But in the meantime, in 2002-04 in particular, output and employment were higher than otherwise expected because of such policies. ${ }^{13}$

Temporary income tax changes have little effect on spending for individuals. An interesting illustration of this principle occurred in 2001 when the tax rate cut on the first $\$ 12,000$ (\$6000) of taxable income for a married couple filing jointly (single) was cut to 10 percent from 15 percent. The saving from this cut was mailed to taxpayers as a one-time check payment, a "pre-bate." While the tax rate cut was permanent, consumers knew they would

\footnotetext{
${ }^{13}$ Many analysts point out that such an effect on the intertemporal investment could have efficiency effects on wealth accumulation, reducing the rate of return on the additional capital put in place early because of the incentives. In principle, the size of such effects is relatively small, however.
} 
not receive another check. Hence they treated the tax cut initially as a one-time or temporary tax rebate. Temporary individual tax cuts have no effect on spending, unlike temporary business tax cuts. The reason is that individuals' assessments of their permanent or longer-term income - the income that affects consumer spending —is unaffected by a onetime or temporary tax cut. Such a tax cut is typically saved or used to pay off credit card debt, so that overall national saving is unaffected-which is why such temporary tax changes are not expected to stimulate spending, output or employment in the economy. ${ }^{14}$

In contrast, permanent cuts in individual tax rates boost private saving and investment. In principle, such a tax cut boosts consumer spending as well, so that private saving does not rise as much as the budget deficit does. The more important effect is that the tax premium in required market yields on debt and equity is reduced, lowering market interest rates despite the budget deficit increase; this, in turn, lowers the cost of capital, which boosts capital formation. ${ }^{15}$ Again, crowding out is not a feature of such tax cuts, even if they lead to deficits. And tax cuts targeted at cutting the tax rate on capital income-such as capital gains taxes or the tax rate on dividends-have even larger positive effects on saving and investment.

The source of deficits also is important for assessing their effects on the exchange rate and international capital flows. For example, cyclical deficits in a recession are associated with lower output and lower interest rates. Capital inflows tend to slow in recessions because of the lowered expectations about short-term real rates of return to investment, so that the dollar falls and net exports improve. The decline in the dollar can be limited by falling imports associated with the recessionary decline in real income. Business tax cuts, in

\footnotetext{
${ }^{14}$ See Shapiro and Slemrod (2001). They show that the rebate component of the 2001 tax cut was largely saved, so that it was treated as temporary. Such a rebate was not a permanent component of the tax cut and respondents to their survey apparently were not even sure that a permanent cut in rates would occur. Other examples of such tax changes that had no effect on the economy's short-term performance or economic growth include the tax surcharge in 1968-69 and the tax rebate in 1975.

${ }^{15}$ This distinction between the effect on interest rates of a cut in personal income tax rates, especially on capital income, such as capital gains or dividends, and a cut in the corporate tax rate is well-known in the literature, but is perhaps the least discussed point in popular textbooks of all the qualifications discussed here. Perhaps the most important discussion of this distinction is Mundell (1960). Brunner (1986, p. 103) explains that there is a difference in the effects of tax cuts on income from human capital and the larger effects of cuts in tax rates on income from nonhuman wealth in his earlier model, Brunner and Meltzer (1976).
} 
contrast, raise budget deficits, but, by raising equity returns and interest rates, they also attract capital inflows and raise the value of the dollar. It is the increased flow of spending on private investment that raises interest rates, however, not a reduced flow of national saving. The deficit change has no direct effect on national saving because it is offset by a rise in private saving, but the improved incentive to save and invest boost interest rates, capital inflows and the dollar. Both deficits (budget and current account) worsen in this case, but investment, productivity, income and growth rise, hardly the doomsday scenario envisioned by deficit critics. Finally, personal income tax cuts have the reverse effects on interest rates, but boost saving incentives so that their positive effects lowering the cost of capital, and raising private investment, international capital inflows and the dollar are associated with lower market interest rates.

\section{Government Spending Is the Problem, Not Taxes}

In conventional analyses of fiscal policy, the strongest case for a deficit increase to boost interest rates occurs when government spending rises and taxes do not. Even in this case, it is not clear that the deficit will boost interest rates, though there is no question that it will crowd-out private sector investment. Crowding-out of private sector spending can occur without higher interest rates. ${ }^{16}$ Government purchases often result in offsetting incentives to reduce private spending.

One important example of crowding-out is government infrastructure investment. Aschauer (1989) has shown that public sector investment expenditures crowd-out, dollar-for-dollar, private sector investment. This occurs because public investment lowers the real rate of return to private-sector activity. ${ }^{17}$ A recent example is the nationalization of airport security services. The rate of return to private sector provision of airport security was depressed enough to bring about an offset to public expenditures on airport security, in both

\footnotetext{
${ }^{16}$ Transfer payments, another potential source of deficits, tend to crowd out private sector transfer payments so that private saving offsets the budget effects of transfer payments. In addition, however, increased transfer payments typically require or are associated with mandatory reductions in supplies of labor or other resources. Hence they tend to reduce overall output.

${ }^{17}$ Gramlich (1994) provides a review of the literature on the effects of public sector capital spending. Tatom (1993) provides US evidence on the effects of public sector capital formation on the private sector. Ford and Poret (1991) provide international evidence that public capital formation does not affect private sector output.
} 
expenditures on capital formation as well as on labor. ${ }^{18}$ Similarly, many other spending programs result in offsetting reductions in private sector spending for similar, perhaps more efficiently produced, goods and services. Examples abound, including school lunch programs, subsidies to state and local government employment of selected workers, and expenditures on education, security and public assistance. E.G. West (1994) details the case for crowding out of private education expenditures from increased public educational expenditures.

\section{Figure 4}

\section{When real federal spending grows faster than the economy, deficits expand}

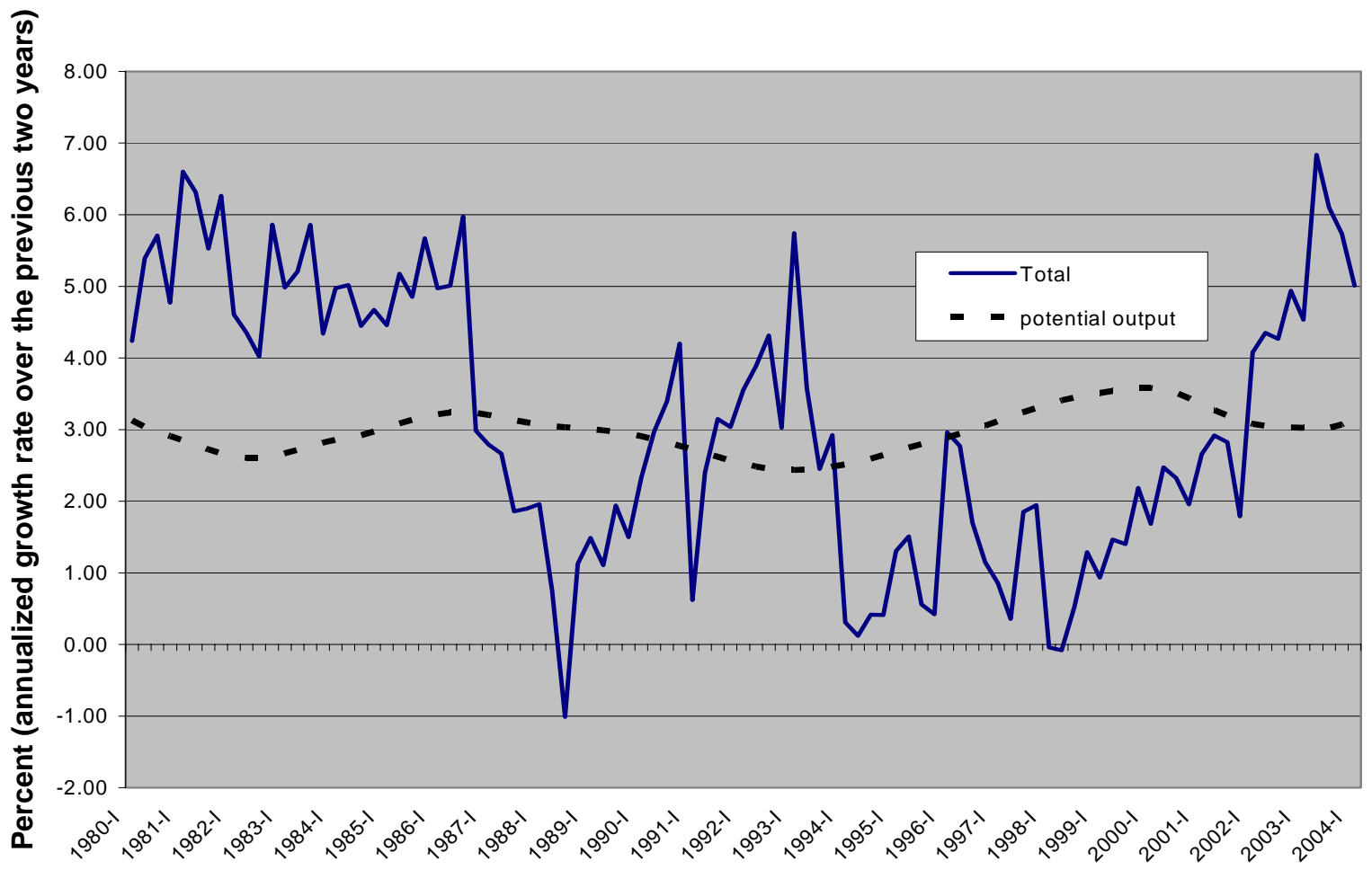

Figure 4 shows the growth rate of real federal expenditures since 1980-where annualized growth rates are measured over the previous two years to smooth the data-along with the

\footnotetext{
${ }^{18}$ Conventional analyses of an open economy provide another example of how crowding out of private sector expenditure can occur without a higher interest rate. If an increase in government spending (or other fiscal actions) pushes up the value of the dollar, it crowds out net exports, boosting the current account deficit. It reduces the future standard of living by raising the debt service cost to foreigners rather than by lowering private sector productivity. This case also rests on unsupported conclusions, however, especially the notion that bigger government spending and/or deficits raise the dollar's value and the current account deficit.
} 
growth rate for the CBO's estimate of the nation's capacity output, or potential GDP. Potential GDP is the national output that could be produced under conditions of high employment of the nation's resources. Conceptually it is the output that would be produced if cyclical variations in the unemployment rate and capacity utilization and their related effects on output were removed. Its growth rate can be used as a benchmark to assess whether federal government expenditures are becoming a larger or smaller share of the nation's GDP. When real spending grows faster than the nation's potential output, the share of government expenditure in potential GDP rises. When spending grows more slowly than potential output, the share of government spending in GDP falls.

The size of government control of resources has been expanding faster than the economy itself, as the government steps up its crowding out of private sector activity. Figure 4 illustrates that from the mid-1980s until 2001 real federal spending growth had been below 2 percent per year and well below the growth rate of potential GDP, except for the surge associated with the first Bush administration and a temporary burst of spending in 1994-96. Government expenditures were finally falling as a share of GDP after an inexorable rise over more than two decades.

Beginning in mid-1998 and starting from near zero, however, spending growth began to accelerate and by the beginning of 2002 it was well above the underlying growth rate of the economy. It reached over 6 percent in 2003, leading to a federal budget deficit of more than $\$ 375$ billion in 2003. The prospects for such spending remain perilous. Congressional Budget Office (CBO) estimates suggests that federal spending will continue to consume a much larger proportion of the nation's income than it did as recently as 2000. As a result, the budget deficit, which returned in mid-2001, will remain for many years to come. 


\section{Conclusion}

Critics of budget deficits assert that they are economically harmful, reducing national saving, increasing interest rates, lowering private investment, and increasing the current account deficit. ${ }^{19}$ These conclusions ignore a wide literature showing that budget deficits are empirically correlated with lower interest rates, not higher, and are statistically unrelated to the current account deficit. It also fails to recognize that the cause of deficits matters for determining their economic impact. Deficits caused by business cycle downturns are associated with interest rate reductions and provide support to aggregate demand, limiting the extent of cyclical decline. Deficits caused by tax reductions also can be beneficial, as they lead to offsetting changes in private saving and investment; deficits caused by tax incentives for capital formation are even more beneficial because their incentive effects boost investment, productivity and growth. When deficits are caused by personal tax rate reductions, required market yields on debt or equity are reduced by the smaller tax premium, reinforcing the negative correlation between budget deficits and interest rates. On the other hand, deficits caused by increased government spending can be harmful due to crowding-out effects, even when these effects are not brought about by higher real interest rates and/or by an increase in the value of the dollar.

\footnotetext{
${ }^{19}$ In this conventional view, the higher interest rate attracts capital flows boosting the currency and the current account deficit. This view ignores the heightened risk of future inflationary policies, higher taxes and rising probability of default. Eventually, if not immediately, the value of the currency falls as global investors come to worry about these risks.
} 


\section{References}

Aschauer, David Alan, "Does Public Capital Crowd Out Private Capital," Journal of Monetary Economics, September 1989, pp. 171-181.

March 1985, pp.117-127.

"Fiscal Policy and Aggregate Demand," American Economic Review,

Bailey, Martin J., National Income and the Price Level: A Study in Macroeconomic Theory, $2^{\text {nd }}$ edition, NewYork: McGraw Hill, 1971.

Ball, Laurence and N. Gregory Mankiw, “What Do Deficits Do?” Budget Deficits and Debt, Federal Reserve Bank of Kansas City, 1995, pp. 95-119.

Barro, Robert J., “Output Effects of Government Purchases,” Journal of Political Economy, December 1981.

Barth, James R., George Iden, Frank S. Russek and Mark Wohar, "The Effects of Federal Budget Deficits on Interest Rates and the Composition of National Output,” in Rudolph G. Penner (ed.), The Great Fiscal Experiment, Washington D.C.: Urban Institute Press, pp. 69129.

Brunner, Karl, "Fiscal Policy in Macro Theory," in Rik Hafer, ed., The Monetary versus Fiscal Policy Debate: Lessons from Two Decades, Totowa, New Jersey: Rowman and Allanheld Publishers, 1986.

, and Allan H. Meltzer, “An Aggregative Theory for a Closed Economy,” and reply, "The Principal Issues: Areas of Argument and Work Remaining, in Jerome Stein, ed., Monetarism, Amsterdam: North Holland, 1976.

Congressional Budget Office, "Deficits and Interest Rates: Theoretical Issues and Empirical Evidence,” January 1989.

, “The Standardized and Cyclically-Adjusted Budget,” March 2003.

, The Budget and Economic Outlook: An Update, August 2003.

, The Cyclically Adjusted and Standardized-Budget Measures, March 2004.

Engen, Eric M. and R. Glenn Hubbard, "Federal Government Debt and Interest Rates," paper presented at the American Enterprise Institute, July 9, 2004.

Feldstein, Martin, “Budget Deficits, Tax Rules, and Real Interest Rates,” National Bureau of Economic Research No. 1970, July 1986. 
de Serres, Alain and Florian Pelgrin, "The Decline in Private Saving Rates in the 1990s in OECD Countries: How Much Can Be Explained by Non-Wealth Determinants?” OECD Economics Department Working Paper Number 344, December 2002.

Ford, Robert and Pierre Poret, "Infrastructure and Private Sector Productivity," OECD Working Paper, Jan. 3, 1991.

Gale, William G. and Peter R. Orszag, "The Economic Effects of Long-Term Fiscal Discipline,” Urban-Brookings Tax Policy Center Discussion Paper No. 8, April 2003.

Gramlich, Edward M., Infrastructure Investment: A Review Essay,” Journal of Economic Literature 32, No, 8 (Sept. 1994), pp. 1176-96.

Kliesen, Kevin L, "Die Another Day? Budget Deficits and Interest Rates." National Economic Trends, Federal Reserve Bank of St. Louis, December 2002.

Kliesen, Kevin L. and Daniel L. Thornton, "The Expected Federal Budget Surplus: How Much Confidence Should the Public and Policymakers Place in the Projections?” Federal Reserve Bank of St. Louis Review, March/April 2001, pp. 11-24.

Kormendi, Roger, "Government Debt, Government Spending and Private Sector Behavior," American Economic Review, December 1983, pp. 994-1010.

and Aris Protopapadakis, "Budget Deficits, Current Account Deficits, and Interest Rates: Systematic Evidence on Ricardian Equivalence," unpublished paper, University of Michigan Business School and University of Southern California, April 2004.

Laubach, Thomas, "New Evidence on the Interest Rate Effects of Budget Deficits and Debt," Finance and Economics Discussion Series 2003-12. Board of Governors of the Federal Reserve System, May 2003.

Mankiw, N. Gregory, Macroeconomics, Worth Publishers, Inc., $5^{\text {th }}$ edition, 2002.

Mueleisen, Martin and Christopher Towe, "U. S. Fiscal Policies and Priorities for Long-Run Sustainability,” International Monetary Fund, Occasional Paper \#27, January 2004.

Mundell, Robert A., "The Public Debt, Corporate Income Taxes, and the Rate of Interest," Journal of Political Economy 68, (December 1960), pp. 622-26, as adapted in the author's Monetary Theory, Inflation, Interest and Growth in the World Economy, Pacific Palisades, California,: Goodyear Publishing, 1971.

Rubin, Robert E., Peter R. Orszag and Allen Sinai, "Sustained Budget Deficits: Longer-Run Economic Performance and the Risk of Financial and Fiscal Disarray," Paper presented at the Annual Meetings of the American Economics Association, January 4, 2004. 
Shapiro, Matthew D. and Joel Slemrod, "Consumer Response to Tax Rebates," National Bureau of Economic Research Working Paper 8672, December 2001.

Tatom, John A., "Is An Infrastructure Crisis Lowering the Nation's Productivity?" Federal Reserve Bank of St. Louis Review (November/December 1993), pp. 3-21.

Tax Foundation, “The President's FY 2005 Budget in Perspective: Part I,” Fiscal Facts, February 2, 2004.

West, E. G., Education and the State, A Study in Political Economy, $3^{\text {rd }}$ revised edition, Liberty Fund, 1994. 